\title{
Collective Trademark as Alternative of Joint Brand Protection for Dupa Harum Kekeran in Bali
}

\author{
A.A.A. Ngurah Sri Rahayu Gorda*, Ni Luh Putu Resti Anggreni* ${ }^{* *}$ \\ DOI: https://doi.org/10.22304/pjih.v7n1.a4
}

Submitted: December 26, 2019 | Accepted: April 30, 2020

\begin{abstract}
In Kekeran Village, Penebel District, Tabanan Regency, people's understanding on the importance of legal protection of Intellectual property rights over brands are not wellestablished. In the village, Dupa Harum Kekeran, a kind of fragrance incense, is the product of a group of women. They use the Kekeran logo; and the logo has not been registered to the Directorate General of Intellectual Property Rights. Brand is a sign that enables customers to identify and differentiate products of companies. As a differentiator, it can also be a marker of an item's reputation. The study employed an empirical legal research method by using primary and secondary data which were analyzed descriptively and qualitatively. The study concludes that collective trademark can be used as an alternative of legal protection. It can be used to reduce business competition in the Tabanan Regency. Legal protection is preventive and can be used together to reduce the level of business competition among the makers of Dupa Harum Kekeran. In particular, the business competition is managed by the home industry. Therefore, legal protection through a collective trademark can be more effective and efficient. The government has to cut the bureaucracy of brand registration and the trademark registration can now be done online. The role of the government in efforts to provide the collective trademark protection can be said to be very optimal.
\end{abstract}

Keywords: brand protection, collective trademark, dupa harum kekeran

\section{Merek Kolektif Sebagai Alternatif Perlindungan Merek Bersama Untuk Produk Dupa Harum Kekeran di Bali}

PADJADJARAN Journal of Law Volume 7 Number 1 Year 2020 [ISSN 2460-1543] [e-ISSN 2442-9325]

* Lecturer of Law, Universitas Pendidikan Nasional, Jalan Waturenggong No. 164 Panjer 80225 Denpasar Bali, S.H. (Universitas Pendidikan Nasional Denpasar), M.M. (Universitas Mahendradatta), M.H. (Universitas Airlangga), Dr. (Universitas Brawijaya), srirahayu@undiknas.ac.id

** Postgraduate Students of Law, Universitas Pendidikan Nasional, Jalan Waturenggong No. 164 Panjer 80225 Denpasar Bali, S.H. (Universitas Pendidikan Nasional Denpasar), email: anikresti17@gmail.com 


\begin{abstract}
Abstrak
Pengetahuan masyarakat Desa Kekeran, Kecamatan Penebel, Kabupaten Tabanan dalam memahami pentingnya perlindungan hukum Hak kekayaan intelektual atas merek masih rendah. Hal ini dapat teridentifikasi ketika Dupa Harum sebagai hasil produksi kelompok ibu-ibu yang menggunakan logo Kekeran dan belum melakukan pendaftaran merek ke Direktorat Jendral Hak kekayaan intelektual. Merek merupakan tanda bagi barang yang ditujukan untuk mengidentifikasi dan membedakan produk suatu perusahaan dengan perusahaan lain. Sebagai pembeda dari satu barang dengan barang lainnya dari merek pula dapat dikenal bagaimana kualitas suatu barang. Metode penelitian yang digunakan adalah metode penelitian hukum empiris, dengan menggunakan jenis data primer dan data sekunder yang selanjutnya dianalisis secara deskriptif kualitatif. Hasil penelitian yang dapat digunakan sebagai alternatif perlindungan hukum adalah merek kolektif. Merek kolektif dapat digunakan untuk mengurangi persaingan usaha di daerah Kabupaten Tabanan. Perlindungan hukum yang bersifat preventif dan dapat digunakan bersama-sama dalam mengurangi tingkat persaingan usaha di antara para pembuat Dupa Harum. Khususnya persaingan usaha yang dikelola industri rumah tangga (home industry). Sehingga perlindungan hukum dengan melalui merek kolektif dirasa lebih efektif dan efisien. Pemerintah yang sudah memangkas birokrasi pendaftaran merek, dan pendaftaran merek kini dapat dilakukan dengan sistem online. Peran pemerintah dalam upaya memberikan perlindungan merek kolektif Dupa Harum Kekeran dapat dikatakan sudah sangat maksimal.
\end{abstract}

Kata kunci: dupa harum kekeran, merek kolektif, perlindungan merek

\title{
A. Introduction
}

Indonesia has ratified several international conventions. Therefore, the role of brand and geographical indications becomes very important in maintaining fit-andfair business competition; consumer protection; the protection of micro, small, and medium enterprises; as well as domestic industry. Brands improve services and provide legal certainty for the industrial world. Brand becomes an identity for a product that becomes symbol, which then is an asset for producer. Identity explains the quality of an item and it characterizes product.

There are still some acts of piracy on goods. Piracy, at least, disrupts economic stability and consumer protection guarantees for goods. ${ }^{1}$ Brand is one of the property rights that arise from the work of human thought. It is a form of regulation in the scope of intellectual property rights. A brand is a sign for goods intended to identify and differentiate a product with other products. As a marker of an item that differentiates an item to other similar items, it can also be a reference of the item's quality. ${ }^{2}$

Hery Firmansyah, Perlindungan Hukum Terhadap Merek, Yogyakarta: Pustaka Yustisia, 2011, p. 29.

Rahmi Jened Nasution, Interface Hukum Kekayaan Intelektual dan Hukum Persaingan, Jakarta: PT. RajaGrafindo Persada, 2013, p. 205. 
The importance of brand in determining the quality of goods implies that every person or organization of a company that manufactures the goods will be very concerned in determining name and symbol used in conducting business and marketing of goods and services. These symbols help to indicate the origin of goods or services, as well as commercial companies engaged in and providing goods and services. These names and symbols are known as trademarks, business names, and company names. ${ }^{3}$

As the identity of a product, a brand must be registered so that it gets recognition and cannot be taken by other manufacturers. To get a good reputation, of course some efforts must be made. Brand protection adheres to a constitutive registration system (first to file). The rights will be obtained after brand is registered. ${ }^{4}$ From the consumer's point of view, brand can be a marker of a product that shows the producer. Consumers can choose certain products from particular manufacturer among other similar products. ${ }^{5}$ In addition to brand protection, there is also legal protection of collective trademark where the rights belong to the recipient party carrying out effective supervision in accordance with the provisions on the use of the collective trademark. Transfer of rights to a collective trademark must be filed with the Directorate General for Intellectual Property Rights. ${ }^{6}$ Collective trademark is defined as a trademark that distinguishes the geographical origin, material, and method of manufacture or other general characteristics of goods or services. In relation to goods and services, a collective trademark indicates that the maker or supplier of goods, or service provider, is a member of the organization or group represented by the collective trademark. This usage indicates that the goods or services are produced by the collective trademark owner and represent products according to those provided directly by the brand owner. ${ }^{7}$

Brand or trademark protection is closely related to trademark disputes. For instance, in the Denpasar District Court Case Tracking Information System, the study found a case with Case Register Number: 1081/Pid.Sus/2019/PN Dps. The case began after PT. Madurana Bali Confection, which in collaboration with PT. BALILAB produce all types of clothing on demand, including shirts, shirts, dresses, skirts, bag pants, and others, used BALILAB brand. The BALILAB brand is claimed as trademark rights by CV. BALILAB based on the Trademark Certificate Number IDM000628603, issued by the Director General of Intellectual Property Rights of

\footnotetext{
Rahmi Jened, Hukum Merek dalam Era Global \& Integrasi Ekonomi, Jakarta: Prenadamedia Group, 2015,p. 3 Suyud Margono, dan Longginus Hadi, Pembaharuan Perlindungan Hukum Merek, Jakarta: CV. Novindo Pustaka Mandiri, 2002, pp. 28-29.

5 Yayan Hanapi, "Pelaksanaan Perlindungan Hukum Merek Untuk Pengusaha Kerajinan Sulaman Karawo di Gorontalo", Gorontalo Law Review, Vol. 1, Issue 2, 2018, p. 5.

$6 \quad$ Anthon Fathanudien, "Alternatif Perlindungan Hukum Atas Hak Merek Kolektif Genteng Jatiwangi Guna Mengurangi Persaingan Usaha di Kabupaten Majalengka", Jurnal Unifikasi, Vol. 3, Issue 2, 2016, p. 14.

7 Etty Susilowati, Hak Kekayaan Intelektual dan Lisensi pada HKI, Semarang: Badan Penerbit Undip Press, 2013, pp. 108-109.
} 
the Republic of Indonesia Ministry of Law and Human Rights, dated January 18, 2016 for the BALILAB brand under the name of CV BALILAB.

Kekeran Village of Penebel District, in Tabanan Regency, is a center of Dupa Harum (traditional fragrant incense) product. The producers mostly use Kekeran logo. Unfortunately, most of the producers, which mostly are homemakers, have low understanding of the importance of legal protection intellectual property rights, especially in the field of brands. Most groups have used the Kekeran logo for years and do not register their trademarks to the Directorate General of Intellectual Property Rights. Most of the producers do not yet know and understand the importance of brand protection for legal certainty and fair business competition. Based on the background of the problem, this article will answer some issues. First, can collective trademarks be used as an alternative brand protection to reduce business competition in the Tabanan Regency area? Second, what is the responsibility of the government to provide collective trademark protection for Dupa Harum Kekeran?

The study employed empirical legal approach with qualitative descriptive methods. Empirical legal research functions to see law in a real sense and to examine public and government awareness of the importance of law. The empirical method can be said as sociological legal research. It takes facts in a society, legal entity, and government agency. ${ }^{8}$ For the data collection techniques, the study used interviews and documentation. Determination of informants in this study was carried out with purposive sampling technique. It is a sampling technique for data sources with certain considerations ${ }^{9}$ where the selection is done deliberately based on predetermined criteria and determined based on the research objectives. Data analysis techniques were carried out qualitatively. Qualitative data analysis is a way of research that produces descriptive analytical data, which is the statements of respondents and their behavior.

\section{B. Collective trademark Can Be Used as an Alternative for Brand Protection to Reduce Business Competition in The Tabanan District}

\section{Collective Trademark as Legal Protection for Trademarks}

Creativity is a spirit of the creative industry. To be able to survive, a creative industry needs to maintain and develop creativity. Thus, the legal regime of the intellectual property rights can be used as a key to run a creative industry. A creative industry that is maintained and developed will be able to adapt in very

Sugiyono, Metode Penelitian Hukum, Surabaya: Pustaka Abadi, 2008, p. 107.

Sugiyono, Metode Penelitian Kuantitatif, Kualitatif, dan R\&D, Bandung: CV. Alfabeta, 2013, pp. 218-219. 
fierce market competition. ${ }^{10}$ Trademark cannot be separated from the intellectual property rights because a trademark or a brand is a part of intellectual property rights. In addition to trademark, other intellectual property rights are copyrights, patents, trade secrets, industrial design, integrated circuit layout design, and protection of plant varieties. Trademark is classified as intellectual property rights because it contains economic rights, which are special rights on intellectual property rights. These economic rights are in the form of profits from the amount of money obtained due to the use of intellectual property rights or because of the use of another party based on a license. ${ }^{11}$ According to Cornish in Susilowati, intellectual property rights protect the use of ideas and information that have commercial or economic value. ${ }^{12}$ The types of trademarks that have been registered in Tabanan Regency can be seen as follows.

Figure 1: Circle Graph

Circle Graph: List of SMEs Registering IPR (Brand Rights) in Tabanan Regency, Period: December 31, 2016

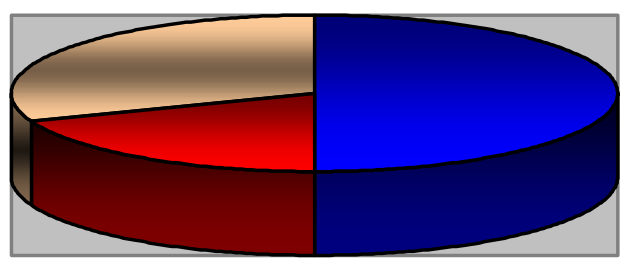

\begin{tabular}{|l} 
Conscious Brand \\
Protection = 76 Business \\
Publish Brand = 29 \\
businesses \\
Brand Not Issued = 47 \\
Businesses
\end{tabular}

Data Sources Processed: Tabanan Regency Cooperative and Small and Medium Enterprises Agency

From the data, there is still no Dupa Harum Kekeran brand registration request. In addition, of 76 businesses that have registered their trademark in 2016, only 29 types of businesses the trademark rights issued by the Directorate General of Intellectual Property Rights in 2018. The data above also shows that, mostly, the people of Penatahan Village, Penebel District, Tabanan Regency as industrial centers of Dupa Harum Kekeran do not understand the importance of brands and are still less aware of the importance of legal protection of brands. The makers of Dupa Harum Kekeran that develops environmentally friendly incense product have

10 Muhammad Fahmi Rois, Kholis Roisah, "Perlindungan Hukum Kekayaan Intelektual Kerajinan Kuningan Tumang Intellectual Property Law Protection on Brass Tumang Crafts", Kanun Jurnal IImu Hukum, Vol. 20, Issue 3, 2018, pp. 401-419. p.7

11 Gatot Supramono, Menyelesaikan Sengketa Merek Menurut Hukum Indonesia, Jakarta: Rineka Cipta, 2008, p. 13.

12 Etty Susilowati, Kontrak Alih Teknologi Pada Industri Manufaktur, Yogyakarta: Genta Press, 2007, p. 106. 
not registered their trademarks to the Directorate General of Intellectual Property Rights as the basis for legal protection, which is actually fully regulated in the Law Number 20 of 2016 on Trademarks and Geographical Indications. The era of global trade, and in line with international conventions that have been ratified by Indonesia, signify the importance of brand, especially in maintaining fair business competition. Growth-oriented economic development alone will not guarantee an increase in the standard of living of the people. Economic growth does not always mean improvements in the distribution of people's income. Growth oriented development cannot guarantee the level of welfare of the people. Therefore, it needs to be more empowered to be more independent, and be able to exploit the potential that exists around the area. ${ }^{13}$ Based on the interview with the Tabanan Regency Cooperatives and SMEs Office represented by I Ketut Antara, problems that occurred from the 76 businesses in 2016 submitting applications for trademark registration mostly include the similarity to other parties. Therefore, the ministry refused and that was the reason for the refusal. The Cooperative Office did not know the reason of the refusal since it was released and listed in the internet. ${ }^{14}$

This study is in the position to see that the business actors have the awareness to register their trademarks to get legal protection from the State. However, the rejection of the proposals clearly confuses the public. The role of government is to campaign collective trademarks to reduce the level of business competition among entrepreneurs who have a similar type of business to be more effective and efficient.

\section{Preventive Legal Protection}

Legal protection is any effort that can guarantee legal certainty. It should be able to provide legal protection to the parties concerned or those taking legal actions. One of the characteristics, and at the same time is the goal of the law, is to provide protection to the people. Legal protection must be realized in the form of legal certainty.

According to Hadjon the means of preventive legal protection is to prevent disputes. ${ }^{15}$ Awareness on the registered trademark rights is one of the preventive protection measures that can be carried out by members of the group making Dupa Harum Kekeran. It is intended as legal protection to prevent acts that violate intellectual property rights for business actors. In the interview, I Ketut Antara said

13 Noning Verawati, (et.al), "Pemberdayaan Masyarakat Bratasena Melalui Usaha Ekonomi Kreatif Telur Asin Rendah Kolesterol”, Jurnal Universitas Bandar Lampung, Vol. 8, Issue 1, 2016, p. 1. See also Agus Mardiyanto, (et.al), "Implementasi Perlindungan Hukum terhadap Hak Kekayaan Intelektual Masyarakat Asli/Tradisional di Kabupaten Purbalingga", Jurnal Dinamika Hukum, Vol. 13, Issue 1, 2013, pp. 25-38.

14 Interview with I Ketut Antara on June 2019.

15 Phillipus M. Hadjon, Perlindungan Hukum Bagi Rakyat di Indonesia $\iota_{2}$ Cetakan Pertama, Surabaya: PT. Bina Ilmu, 1998, p. 30. 
that the SMEs currently feel that they do not need their intellectual property rights protected but the Tabanan Regency Cooperative and SME Office have often informed and facilitated anyone who wants to register their trademarks. Unfortunately, business owners do not consider the trademark to be important. ${ }^{16}$

According to Hasanah, legal protection is any effort that can guarantee legal certainty. Therefore, it can provide legal protection to the parties concerned or those taking legal actions. ${ }^{17}$ Protection of intellectual property rights was originally a form of state's protection for idea or work of its citizens. Intellectual property rights are essentially territorial in nature. Intellectual property is useful for protecting ideas and the use or imitation by unauthorized parties. Intellectual property rights law also makes it possible for employers to prosecute, in both criminal and civil courts, any parties who violate their copyrighted works, art, creations without rights. The protection of intellectual property rights can be implemented with two systems: declarative and constitutive. ${ }^{18}$ It includes the protection of trademark rights. Declarative protection system is a system where those who get legal protection are the first users of the trademark concerned. ${ }^{19}$

According to Saidin, a trademark is a sign to distinguish similar goods or services produced or traded by a person or a group of people or a legal entity that is unique compared to similar goods or services produced by other parties. It has a distinguishing power and as collateral for quality and used in trading goods or services. ${ }^{20}$ Dupa Harum Kekeran uses environmentally friendly materials with sandalwood and agarwood aroma. It uses the pure wood directly as a mixture of its direct dough. It is made by homemakers and can use collective trademarks as a means of preventive legal protection. The government of Tabanan Cooperative Office has tried to implement preventive legal protection tools by socializing trademarks in every entrepreneurial activity and facilitating entrepreneurs who are aware of preventive legal protection to register their business marks. Preventive legal protection here is protection against a criminal act or violation of the law. ${ }^{21}$

According to Hadjon, preventive legal protection tool is proposed to prevent unfair business competition disputes. As a preventive effort in overcoming unhealthy competition in the era of trade, the small-scale producers of Dupa Harum Kekeran should use a collective trademark as an alternative to legal protection. The use of joint marketing through collective trademark does not

Interview with I Ketut Antara, loc.cit.

Hetty Hasanah, loc.cit.

Herlina Ratna S.N., "Analisis Perlindungan Hukum atas Merek Terdaftar sebagai Hak atas Kekayaan Intelektual (Studi pada Kantor Wilayah Kementerian Hukum dan HAM Provinsi Lampung)", Jurnal Keadilan Progresif, Vol. 7, Issue 7, 2016, p. 154.

Ibid.

H. OK Saidin, Aspek Hukum Hak Kekayaan Intelektual, Jakarta: PT. Rajawali Pers, 2016, p. 345.

Meli Hertati Gultom, "Perlindungan Hukum Bagi Pemegang Hak Merek Terdaftar terhadap Pelanggaran Merek", Jurnal Warta, Vol. 56, Issue 2, 2018, p. 7. 
conflict with the Law Number 5 of 1999 on the Prohibition of Monopolistic Practices and Unfair Business Competition. It is because small businesses are excluded according to Article 50, letter h, of the Law. The small business actors are exempt from the application of the Law.

The study considers the collective trademark to be a tool that has very strong power for local development for Dupa Harum Kekeran that have certain special characteristics with only two scents: aloes and sandalwood. They are made from natural raw materials and environmentally friendly. The process may enable them to address weaknesses of marketing activities in earlier periods and to take decisions jointly with local stakeholders and thus improve the quality. ${ }^{22}$

\section{Repressive Legal Protection}

The importance of legal protection in the field of intellectual property rights, especially brands, has often been socialized. Unfortunately, the public often ignores them. There are many violations in the field of intellectual property rights, especially brands, either intentionally or unintentionally. Often, when there are other business actors with similar brands registered in the Directorate General of Intellectual Property Rights. According to Kapferer, brand is an identity structure with six integrated facets of culture, personality, self-projection, physique, reflection, and relationship. ${ }^{23}$

According to Hadjon, repressive legal protection aims to resolving disputes. The handling of legal protection by the General Courts and Administrative Courts in Indonesia falls into this category of legal protection. ${ }^{24}$ Business actors cannot imitate others that have been registered beforehand. The registered trademarks receive legal protection by means of repressive legal protection. Trademark disputes that have occurred can be reported to the Police Office of the business owner's jurisdiction because criminal offenses and/or violations in the field of intellectual property rights constitute offense of complaint. The threat of criminal penalties that can be imposed for business actors who imitate other trademarks is stated in Article 100 of the Law Number 20 of 2016 on Trademarks and Geographical Indications.

According to Rahardjo, legal protection is an effort to protect one's interests by allocating a Human Rights power to act in the framework of interests. According to Soeryatin, the formula was expressed by reviewing the brand from the aspect of its

\footnotetext{
22 Mechthild Donner and Fatiha Fort, "Place Brand Building", Journal of Product \& Brand Management, Vol. 27, Issue 7, 2018, p. 814.

23 Upendra Kumar Maurya, "What Is a Brand? A Perspective on Brand Meaning", European Journal of Business and Management, Vol. 4, Issue 3, 2012, p.125.

24 Phillipus M. Hadjon, op.cit., p. 30.
} 
function, namely as a trademark used to distinguish the goods in question from being given a trademark, the trademark of origin, name, guarantee of its quality. ${ }^{25}$

Intellectual property rights are exclusive rights granted by the state to individuals to give permission or forbid others to implement economic rights of products protected by intellectual property rights. Repressive legal protection for trademark disputes constitutes offense of complaint. In addition to reporting to the dispute area police station, other repressive legal protection measures can also be through complaints procedures for violations of intellectual property rights through complaints against Civil Servant Investigators Intellectual property rights, hereinafter abbreviated to PPNS IPR Directorate of Investigation and Dispute Resolution, in the Regional Office of the Ministry of Law and Human Rights. Investigators will prepare Minutes of Examination. The investigators also appoint experts to provide opinions of expertise in the case verification stage.

After the verification, the investigator search and inspect evidence, bookkeeping, recording, and other documentation. The file that has been declared complete will be transferred to the Prosecutor's Office, which will then be the basis for prosecution for the Public Prosecutor. The hearing was continued at the District Court to finally get a decision from the Panel of Judges at the hearing. If the parties to the dispute are dissatisfied with the decision of the District Court judges, they can still appeal to the High Court and the final remedy can be taken until the appeal to the Supreme Court.

The study found a trademark dispute recently in the Denpasar District Court with Case Register Number 1081/Pid.Sus/2019/PN Dps. The Public Prosecutor was I Nyoman Agus Pradnyana, S.H., and the Defendant is Badrus Saleh. The case was completed in twenty-eight days. On Monday, October 14, 2019, the Panel of Judges who tried the case decided with the first decision legally and convincingly states that the Defendant is guilty of committing a Criminal Act based on Article 100 and Article 101 of the Law Number 20 of 2016 on Trademark and Geographical Indications. The Panel of Judges impose a fine of Rp15.000.000,00 (fifteen million rupiahs) to the Defendant provided that the fine is not paid and replaced with a sentence of imprisonment for one month.

Collective trademarks are regulated in Article 7 bis the Paris Convention for the Protection of Industrial Property Rights (1883/1967). Pursuant to Article 7 of the Paris Convention, member states must accept the registration of collective marks owned by associations whose existence does not conflict with the rule of law of origin, even if the association does not have a commercial or industrial establishment in that state. Each state assesses certain conditions whereby the

25 H. OK Saidin, op.cit., p. 343. 
collective trademark is protected or registration may be denied if the collective trademark is against the public interest. ${ }^{26}$

Based on the interview with a member of Kekeran group, Deli Ekayanti, who is also the coordinator of forty group members, the production of Dupa Harum Kekeran already exists since 2017, which was only intensively worked on in mid2018 until now. Dupa Harum Kekeran only focuses on two aromas: Aloes and Sandalwood. Regarding the brand, they do not think that they need a brand, it is enough with the logo that reads Dupa Harum Kekeran as a characteristic of their incense. In addition, they also do not understand the importance of brand. ${ }^{27}$

Brand problems are closely related to unfair competition. ${ }^{28}$ If entrepreneurs in a similar field jointly try in the same area, each of them tries to get a place in the hearts of the consumers. Competitive not only those at stake, more than that at stake is the quality of goods or financial products and services. The Law Number 5 of 1999 on the Prohibition of Monopolistic Practices of Unfair Business Competition intended to provide legal certainty and equal protection to every business actor in doing business by preventing monopolistic practices and/or other unfair business competition with the hope of creating a conducive business climate, where every business actor can compete fairly. ${ }^{29}$

The chances of unfair business competition, which is the impact of business competition practices, will continuously increase. The condition of business competition in some respects also has negative aspects. For instance, if dishonest economic actors, contrary to the public interest, carry out a competition, it will lead to economic instability of the people. The extreme risk of competition is of course the possibility of adopting unfair competition practices because competition is seen as an opportunity to get rid of competitors in any way. ${ }^{30}$

The collective trademark can be used as an alternative protection for the Dupa Harum Kekeran brand. The trademark has not been registered at the Directorate General of Intellectual Property Rights. Based on the interview with Wayan Wiartini, Ni Wayan Suciati, Luh Putu Suardani, and Kadek Nirmala (business operators of Dupa Harum Kekeran), there are several reasons for the makers of the Dupa Harum Kekeran to be unregistered.

1. They do not aware yet of intellectual property rights, especially regarding legal protection of brands.

\footnotetext{
26 Rahmi Jened, Hukum Merek (Trademark Law) Dalam Era Global dan Integrasi Ekonomi, Jakarta: Kencana Prenadamedia Group, 2015, p. 275

27 Interview with Deli Ekayanti on August 2019.

28 H. OK. Saidin, op.cit., p. 356.

29 Devi Meyliana, Hukum Persaingan Usaha: Studi konsep pembuktian terhadap perjanjian penetapan harga dalam persaingan usaha, Malang: Setara Press, 2013, pp. 15-16.

30 Galuh Puspaningrum, Hukum Persaingan Usaha; Perjanjian dan Kegiatan yang Dilarang dalam Hukum Persaingan Usaha di Indonesia, Yogyakarta: Aswaja Pressindo, 2013, p. 71
} 
2. It is rare for a dispute over a trademark to be filed to court. Therefore, the producers of Dupa Harum Kekeran feel that it is not important to entry for registration.

3. Registration fee is considered expensive. The time to arrange trademark registration is too long. They also do not know the terms and procedures, making them reluctant to register.

4. The registration process seems not easy and spends a lot of time, in addition to the possibility of proposal rejection. ${ }^{31}$

Business competition that occurs in the era of free trade makes the company always striving to provide assurance that their products can meet customer satisfaction. The condition of competition is actually a characteristic attached to human life that tends to outperform each other in many ways. ${ }^{32}$ Indonesia's participation in international trade has pushed Indonesia to ratify the convention on the Establishment of the World Trade Organization, which includes agreement on Trade Related Aspects of Intellectual Property Rights. ${ }^{33}$

According to Rokan, monopoly means the condition of control of production and marketing by a certain group of business actors. Monopolistic practice emphasizes concentration of power resulting in monopolistic market conditions. Therefore, monopolistic practices do not practically create monopolies but this term generally describes an attempt to achieve or strengthen a dominant position in the market. The right of monopolistic practice may consider a number of things like the determination of the relevant market and an assessment of the state of the market as well as the activities carried out by actors to control the market. ${ }^{34}$

Creative economy is an activity carried out at the local level and has the goal of increasing the rate of growth, creating jobs, and increasing income. It is creative, rare, has not been carried out by others, has a significant selling power, and has a domestic market share and extensive export. ${ }^{35}$ The producers of Dupa Harum Kekeran are categorized as micro small businesses. They face constraints in marketing their products. Market a certain product for small businesses is a serious problem because of the lack of information on the market share of the product. This means that small businesses cannot market their goods or services in a good

Interview with Wayan Wiartini on August 2019.

Arie Siswanto, Hukum Persaingan Usaha, Jakarta: Ghalia Indonesia, 2002, p. 13.

Hafid Zakariya, Nurul Hidayah, "Keberpihakan Pemerintah dalam Mendukung Daya Saing UMKM Melalui Pendaftaran Merek Kolektif, Daya Saing UMKM Melalui Pendaftaran”, Jurnal Serambi Hukum, Vol. 10, Issue 2, 2016, p. 6.

34 Mustafa Kamal Rokan, Hukum Persaingan Usaha: Teori dan Praktiknya di Indonesia, Jakarta: Rajagrafindo Persada, 2010, pp. 9-10.

35 Bagus Udiansyah Permana, (et.al), "Strategi Pemberdayaan Masyarakat melalui Inovasi Ekonomi Kreatif dalam Penanggulangan Kemiskinan: Studi Kasus Industri Kerajinan Alat Tenun Bukan Mesin di Kecamatan Purwosari Kabupaten Pasuruan", Jurnal Wacana, Vol. 17, Issue 4, 2014, pp. 246-253. 
or professional manner. As a result, these business actors slam the selling prices of their products for fear of not selling. Eventually, there is unfair business competition among the small business actors. This is happened in the industry of the Dupa Harum Kekeran.

Collective trademarks can be a powerful tool for development of products that have certain special characteristics related to social, cultural, and historical conditions, in a particular region. The existence of a collective trademark can be used together and as a basis for marketing related products. It can provide benefits for all producers in the association of collective trademark owners, for example Micro, Small and Medium Enterprises (MSMEs). It can also increase product recognition. Collective trademarks can also be used together with individual brands of products registered. This allows the company to differentiate its own brand from its competitors and at the same time benefit from consumer trust in the products offered under the collective trademark.

\section{Government Responsibility to Provide Collective Trademark Protection for Dupa Harum Kekeran}

According to Wheeler, brand is "the nucleus of sales and marketing activities, generating increased awareness and loyalty, when managed strategically". In general, the word "brand" can be interpreted as a sign to distinguish similar goods produced or traded by a person or a group of people or a legal entity similar to others. It has the power of differentiation or as collateral for quality and is used in the activity of trading goods or services. The definition of brand in Article 1 Number (1) of the Law Number 20 of 2016 on Trademarks and Geographical Indications is as a sign that can be displayed graphically in the form of an image, logo, name, word, letter, number, color arrangement. The form can be two dimensions and/or three dimensions, sound, hologram, or a combination of two or more of these elements to distinguish goods and/or services produced by persons or legal entities in the trading of goods and/or services.

The study found obstacles in the implementation of brand legal protection. These obstacles come from both Micro Small Business Entrepreneurs and the Tabanan Regency Cooperative Office, Tabanan Regency Industry and Trade Office, and the Bali Provincial Law and Human Rights Office. In the field of Intellectual Property, the government is the responsible party who should provide socialization related to intellectual property rights, especially brands, to MSME entrepreneurs in each Regency, especially in Tabanan Regency. Based on the Finkelstein theory of legal responsibility developed by states, legal responsibility plays its function in modern society (sociological jurisprudence). Here, the government, as in the registration of the trademark, is to facilitate and socialize the importance of 
protecting intellectual property rights, especially trademark. The obstacles the Banjar Kekeran are as follows.

1. The producers of Dupa Harum Kekeran have a weak understanding of the substance of the Law Number 20 of 2016 on Trademarks Brand and Geographical Indications.

2. The public has low level of awareness about the importance of registration of intellectual property rights to protect the work they produce.

3. People feel indifference to the importance of a trademark registration.

4. People assume that no trademark dispute has occurred in the Tabanan Regency.

These obstacles, from the point of view of the Law Number 20 of 2016, are not the reasons not to register the trademark. If there is no good faith from the trademark creator to register the brand, the state will not protect the trademark.

According to Article 3 of the Law Number 20 of 2016, rights to trademarks are obtained after the trademark is registered. The legal assumption is that the first applicant who filed a registration in good faith is the party entitled to the trademark, until proven otherwise. The purpose of this provision is a simplification of the old provisions, which stipulate the registration of a trademark for only one class of goods and services. This is intended to facilitate the owner in using trademark for some goods or services that are included in several classes that should not need to be bothered with administrative procedures requiring a separate application for each class of goods or services. The fee for registration of trademark is still charged in accordance with the number of classes of goods or services requested for registration. ${ }^{36}$

Collective trademark in Indonesia is regulated in Article 46 to Article 51 of the Law Number 20 of 2016 on Trademarks and Geographical Indications. According to Law Number 20 of 2016 on Trademarks and Geographical Indications, Article 1 Paragraph (4), trademark is used on goods and/or services with the same characteristics regarding the nature, general characteristics, and quality of goods or services. It also valid for their supervision, which will be traded by several people or legal entities together to differentiate from other similar goods and/or services.

The purpose of collective trademark is to simplify the completion of a registration request. For example, if ten entrepreneurs produce a same type of goods or service, they must submit a registration request to protect each of the intended goods or services. On the other hand, each of the goods or services produced and traded has the same characteristics. In this case, it is possible to use only one brand. For all types of goods or services, only one application for

$36 \quad$ Rahmi Janed, op.cit., pp. 144-145. 
registration of a trademark is required for their collective use. Then these entrepreneurs can save money, time, and energy to process registration requests. Based on the interview with I Ketut Antara, awareness of brand protection in Indonesia is very low because Indonesia has the lowest awareness of registering brands. Ideally, brand should have been registered before the business is developed. Later, it will develop and the idea will not be stolen. Before someone else registers first in the system, trademark should be immediately registered. Whoever registers first is entitled to the trademark. ${ }^{37}$

Registration of a trademark or service is useful to protect product from misuse of brand names by other parties without permission from the registered trademark owner. Other registered trademarks will definitely not be able to register again because this trademark is a monopoly right of the registered trademark owner. Registration of a trademark is regulated and protected by the Law Number 20 of 2016 on Trademarks and Geographical Indications, which is still valid today. New brand holders will be recognized for their trademark ownership if the trademark is registered. ${ }^{38}$

Indonesia adheres to the trademark registration system with a constitutive system. This system requires the registration of trademark for protection. This system is also known as the first to file system. This system confirms that the person who first registered the trademark has the trademark rights. Even though Indonesia adheres to trademark registration based on a constitutive system, famous trademarks that have not been registered in Indonesia is still protected because Indonesia has ratified the Paris Convention and the TRIPS Agreement (The World Trade Organization's TRIPS Agreement). ${ }^{39}$

The study is in the position to propose a simplification to the trademark registration process flow based on Law Number 20 of 2016 on Trademarks and Geographical Indications as follows.

Interview with I Ketut Antara, loc.cit.

38 Novi Dharmawati, (et.al), "Analisis Pelanggaran Merek Dagang dalam Kasus Persamaan Bentuk Kemasan oleh PT. Sinde Budi Sentosa (Cap Badak) Terhadap Wen Ken Drug Co. (PTE) LTD. (Cap Kaki Tiga)", Jurnal Privat Law, Vol. 2, Issue 5, 2014, p. 16.

39 Rakhmita Desmayanti, "Tinjauan Umum Perlindungan Merek Terkenal Sebagai Daya Pembeda Menurut Perspektif Hukum Di Indonesia", Jurnal Cahaya Keadilan, Vol. 6, Issue 1, 2018, p. 8. 
Figure 2: Proposed Flow Chart

\section{PROPOSED TRIMMING PROCESS FLOW REQUEST FOR \\ TRADEMARK REGISTRATION \\ BASED ON LAW NO. 20 OF 2016}

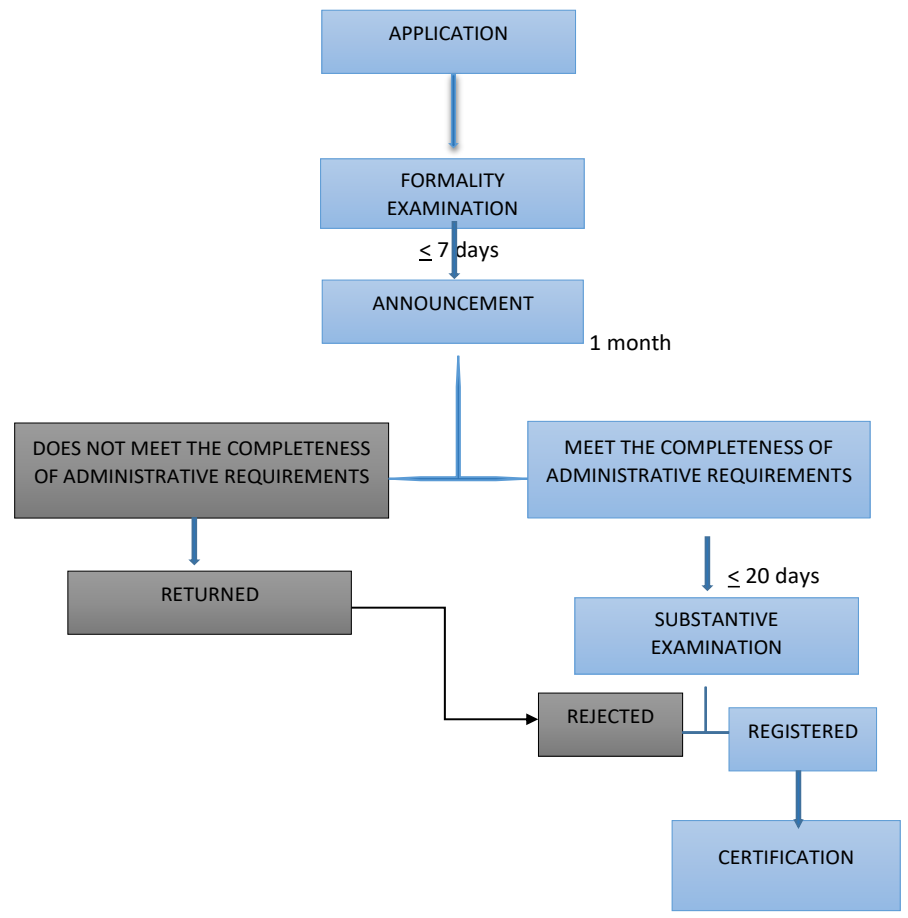

Article 11 of the Law Number 20 of 2016 stipulates that the Directorate General of Intellectual Property Rights conducts checks on the lack of completeness of trademark registration requirements as referred to in Article 4, 5, 6, and/or 7 . There is a shortage in the completeness of the requirements referred to in Article 10. The Directorate General of Intellectual Property Rights requests that the completeness of these requirements be fulfilled within a maximum period of three months from the end of the application submission period by using Priority Rights. Article 12 of the Law states that in the event that the requirements are not fulfilled within the period referred to in Article 11, the minister notifies in writing the Applicant or the Proxy that the application is considered pulled back. Applications for trademark registration that have arrived at the Tabanan Regency Cooperative and Small and Medium Enterprises Office will continue to be examined again. Once 
the application requirements have met the requirements, they will be sent to the Bali Provincial Law and Human Rights Office for registration. Domestic registration may register by coming in person or authorizing an attorney. Foreign brand owners are required to register through their attorneys who practice in Indonesia. Foreign companies that will register their trademarks must also have a representative office in Indonesia. Based on the interview with the Regional Office of Law and Human Rights in the Province of Bali, Mr. Putu Edi Wayudi, SH, from the Sub Division of Intellectual Property Rights Services on Friday, 27 September 2019, Since August 17, 2019, the Director General of intellectual property rights has registered registration intellectual property rights, especially trademarks online. Therefore, from now on, the community can register their trademarks independently but the online system is only limited to registration. Address and extension of trademark rights must still be processed in the Regional Office. Before starting to make a brand application, the application user can prepare an application document that will be uploaded as an application attachment. ${ }^{40}$

In order to be eligible to be able to register a trademark online, we must have an e-filing account. The user of the e-filing application can prepare application documents to be uploaded as appendices. The following is a picture of the Directorate General of Intellectual Property Rights e-Filing scheme.

Figure 3: e-Filing Service Scheme of DG HK

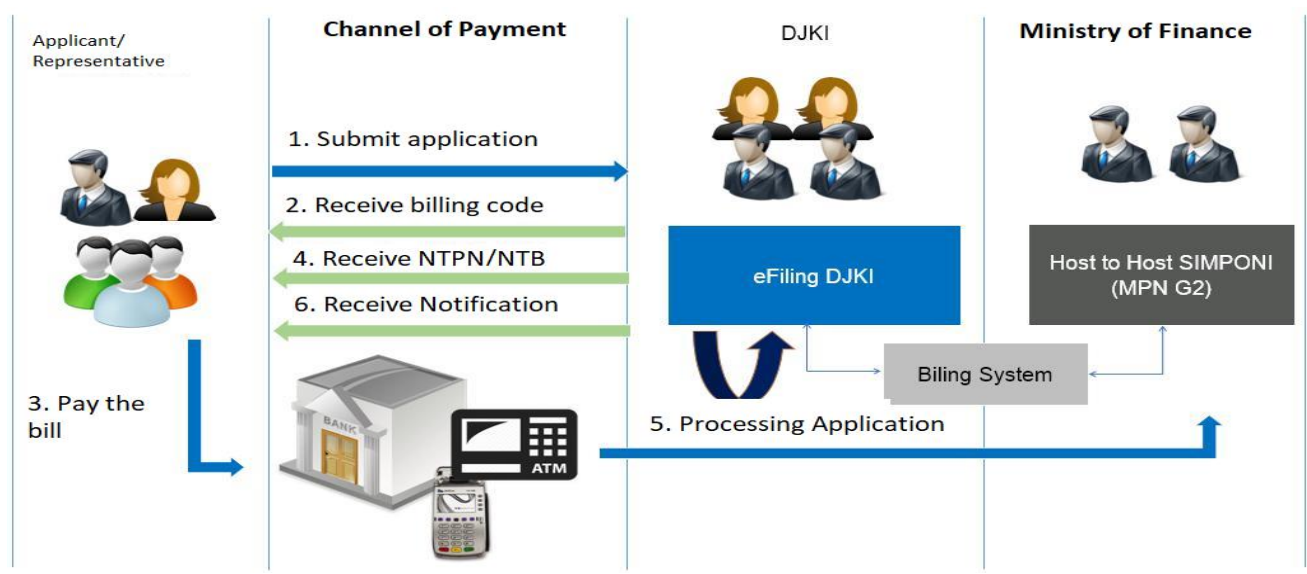

Explanation of the picture:

1. Applicant fills in the data and uploads the attachment to submit the application.

2. Applicant receives the billing statement receives the SIMPON billing code.

$40 \quad$ Interview with Putu Edi Wayudi on September 2019 
3. Applicant pays for the SIMPONI billing code at the Bank/Perception Post.

4. Applicants receives NTPN as proof of state revenue.

5. Request is submitted via e-filing will be accepted by the DJKI (the applicant receives the application number).

6. Application status is accepted.

7. Applicant can download the application form.

An application for a trademark must also be rejected if it has similarities in principle or in whole with another party's registered trademark for similar goods or services; or it has similarity in principle or in whole with a known geographical indication. There is no trademark rights without registration. This registration brings more certainty because if someone can prove to have registered a trademark and is approved, then that other person is not entitled to use the same trademark on similar items as well. Therefore, this constitutive system provides more certainty.

The following is a comparison of Incense products whose brands have been registered and those that have not been touched by brand protection in the Tabanan Regency market.

Figure 4: Comparison Table of Dupa Harum (Fragrant Incense) that Has and Has Not been Registered ${ }^{41}$

\begin{tabular}{|c|c|c|}
\hline No. & Unregistered & Registered \\
\hline 1. & 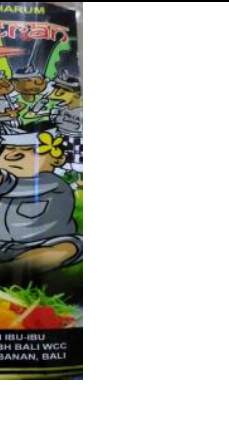 & 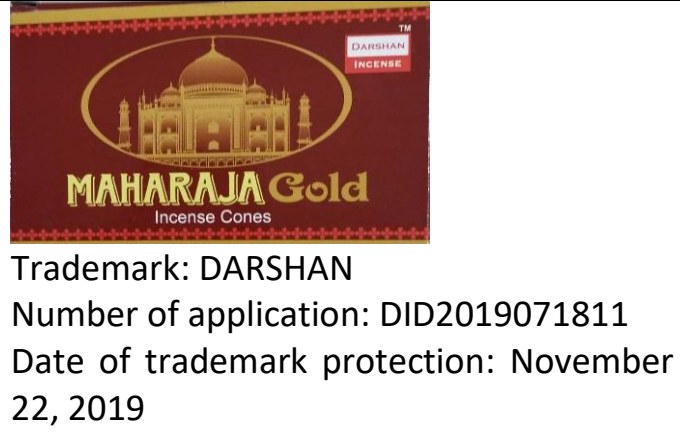 \\
\hline
\end{tabular}

$41 \quad$ Ibid. 


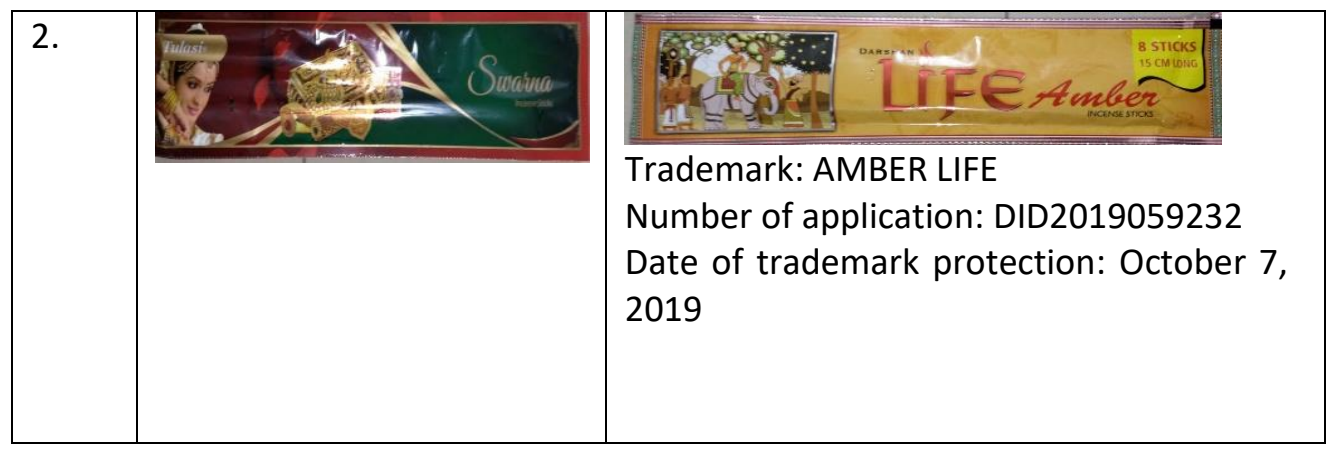

The function of registered trademarks is to obtain legal protection. Owner is entitled to a trademark that is protected legally. Article 3 and 4 of the Law Number 20 of 2016 on Trademarks and Geographical Indications essentially states that the right to a trademark is an exclusive right granted by the State to the owner of the registered trademark for a certain period by using it or licensing it to another party by good faith. Based on the exclusive rights or the special rights, other people are prohibited from using a registered trademark for goods or services of the same type, unless previously obtained permission from the owner of the registered trademark. If this is violated, the illegal registered trademark users can be prosecuted both civil and criminal. Based on the interview with Mr. Putu Edi Wayudi, the Ministry of Cooperatives has signed the MoU with the Ministry of Law and Human Rights related to registration of intellectual property rights starting in 2016. Based on the MoU, the Ministry of Cooperatives will issue an SME statement for their brand fostered, for Micro and Small Businesses from the electronic registration fee of five hundred thousand rupiahs. The Cooperative Office, making it look free to register through the Cooperative Service, subsidizes the five hundred thousand rupiahs. However, it is worth noting that the SMEs here refer to Micro Small Businesses not as Small and Medium Enterprises because Small and Medium Enterprises are deemed capable by the government and are categorized as general by paying per class which via electronic (online) pay registration of one million eight hundred thousand rupiah). There is no free registration in PNBP, there are still differences in registration by class. ${ }^{42}$

The Ministry of Cooperatives and the Ministry of Law and Human Rights, based on the theory of government responsibility, are very concerned about the importance of brand protection and striving for convenience and relief for a society that is responsive to the importance of brand protection in the era of global trade. The trimmed path has become easier, and the latest news from August 17, 2019 is to be able to register a trademark through the full online system. Current fee rates

42 Interview with Putu Edi Wayudi, loc.cit. 
cannot be a reason not to register a trademark. The government has many obstacles that people do not want to register their trademarks because registration fees are considered expensive. Now, the government is responsible for facilitating the tariff of Non-Tax State Revenues (PNBP).

The Cooperative Guidance Business Management Letter can be obtained from the Cooperative Office. The new Micro Small Business that is pioneering and responsive to the importance of the brand can attach a Cooperative Guidance Letter to apply for trademark registration from an electronic registration fee of five hundred thousand rupiahs.

\section{Conclusions}

This study draws several conclusions. First, the protection of collective trademark law can be used as an alternative to the protection of the trademark of Dupa Harum Kekeran, namely by using collective trademarks to reduce the level of business competition among the producers. It can be managed by the home industry so that it is more effective and efficient. The Tabanan Regency Government has not yet played a maximal role to protect the Dupa Harum Kekeran brand. The Tabanan Regency Government has a role to protect the brand as an industrial product from Kekeran Village, Penebel District, Tabanan Regency.

The responsibility of the government in the effort to provide protection is very much as possible and very true attention to the importance of brand protection where the Government adds to the socialization system in the region. The government has also cut the bureaucratic registration of trademarks and starting on August 17, 2019 announced that trademark registration can now use the full online system. The Government is very concerned about Small and Medium Enterprises in order to get legal protection, and therefore the Ministry of Cooperatives has the MoU with the Ministry of Law and Human Rights related to registration of intellectual property rights, which issue a certificate of Micro Small Business.

\section{References}

\section{Books}

Ahmad M. Ramli, Cyber Law dan HAKI dalam Sistem Hukum Indonesia, PT. Refika Aditama, Bandung, 2004.

Arie Siswanto, Hukum Persaingan Usaha, Cetakan Pertama, Ghalia Indonesia, Jakarta, 2002.

Devi Meyliana, Hukum Persaingan Usaha "Studi Konsep Pembuktian Terhadap Perjanjian Penetapan Harga Dalam Persaingan Usaha", Setara Press, Malang, 2013. 
Etty Susilowati, Hak kekayaan Intelektual dan Lisensi Pada HKI, Badan Penerbit Undip Press, Semarang, 2013. Kontrak Alih Teknologi Pada Industri Manufaktur, Genta Press, Yogyakarta, 2007.

Galuh Puspaningrum, Hukum Persaingan Usaha; Perjanjian dan Kegiatan yang Dilarang dalam Hukum Persaingan Usaha di Indonesia, Aswaja Pressindo, Yogyakarta, 2013.

Gatot Supramono, Menyelesaikan Sengketa Merek menurut Hukum Indonesia, Rineka Cipta, Jakarta, 2008.

H. OK Saidin, Aspek Hukum Hak Kekayaan Intelektual, PT. Rajawali Pers, Jakarta, 2016.

Hery Firmansyah, Perlindungan Hukum terhadap Merek, Pustaka Yustisia, Yogyakarta, 2011.

Direktorat Jendral Kekayaan Intelektual, Panduan Pengaduan Permohonan Pendaftaran Merek, Desain Industri dan Paten melalui e-Filing DJKI, Kementrian Hukum dan HAM RI, Jakarta, 2018.

Phillipus M. Hadjon, Perlindungan Hukum Bagi Rakyat di Indonesia, PT. Bina Ilmu, Surabaya, 1998.

Rahmi Jened Nasution, Hukum Merek (Trademark Law) dalam Era Global dan Integrasi Ekonomi, Kencana Prenadamedia Group, Jakarta, 2015.

Interface Hukum Kekayaan Intelektual dan Hukum Persaingan, PT. RajaGrafindo Persada, Jakarta, 2013.

Suyud Margono, dan Longginus Hadi, Pembaharuan Perlindungan Hukum Merek, CV. Novindo Pustaka Mandiri, Jakarta, 2002.

Sugiyono, Metode Penelitian Hukum, Pustaka Abadi, Surabaya, 2008.

Metode Penelitian Kuantitatif, Kualitatif, dan R\&D, CV. Alfabeta, Bandung, 2013.

\section{Other Documents}

Anthon Fathanudien, "Alternatif Perlindungan Hukum Atas Hak Merek Kolektif Genteng Jatiwangi Guna Mengurangi Persaingan Usaha di Kabupaten Majalengka", Jurnal Unifikasi, Vol. 3, Issue 2, 2016.

Bagus Udiansyah Permana, (et.al), "Strategi Pemberdayaan Masyarakat melalui Inovasi Ekonomi Kreatif dalam Penanggulangan Kemiskinan: Studi Kasus Industri Kerajinan Alat Tenun Bukan Mesin di Kecamatan Purwosari Kabupaten Pasuruan", Jurnal Wacana, Vol. 17, Issue 4, 2014.

Donner, Mechthild, and Fatiha Fort, "Place Brand Building", Journal of Product \& Brand Management, Vol. 27, Issue 7, 2018. 
Hafid Zakariya, Nurul Hidayah, "Keberpihakan Pemerintah dalam Mendukung Daya Saing UMKM Melalui Pendaftaran Merek Kolektif, Daya Saing UMKM Melalui Pendaftaran, Jurnal Serambi Hukum, Vol. 10, Issue 2, 2016.

Herlina Ratna SN, “Analisis Perlindungan Hukum atas Merek Terdaftar sebagai Hak atas Kekayaan Intelektual: Studi pada Kantor Wilayah Kementerian Hukum dan HAM Provinsi Lampung”, Jurnal Keadilan Progresif, Vol. 7, Issue 2, 2016.

Jufri Halim, (et.al), “Analisis Faktor-Faktor Yang Mempengaruhi Loyalitas Pelanggan Terhadap Kartu Seluler Merek Telkomsel: Studi Kasus Pada Mahasiswa Fakultas Ekonomi ITMI Medan", Jurnal Santikom, Vol. 16, Issue 3, 2017.

Maurya, Upendra Kumar, "What Is a Brand? A Perspective on Brand Meaning", European Journal of Business and Management, Vol. 4, Issue 3, 2012.

Meli Hertati Gultom, "Perlindungan Hukum Bagi Pemegang Hak Merek Terdaftar Terhadap Pelanggaran Merek", Jurnal Warta, Vol. 56, Issue 2, 2018.

Muhammad Fahmi Rois and Kholis Roisah, "Perlindungan Hukum Kekayaan Intelektual Kerajinan Kuningan Tumang Intellectual Property Law Protection On Brass Tumang Crafts", Kanun Jurnal IImu Hukum, Vol. 20, Issue 3, 2018.

Noning Verawati, (et.al), "Pemberdayaan Masyarakat Bratasena Melalui Usaha Ekonmi Kreatif Telur Asin Rendah Kolesterol", Jurnal Universitas Bandar Lampung, Vol. 8, Issue 1, 2016.

Novi Dharmawati, (et.al), “Analisis Pelanggaran Merek Dagang dalam Kasus Persamaan Bentuk Kemasan oleh PT. Sinde Budi Sentosa (Cap Badak) terhadap Wen Ken Drug Co. (PTE) LTD. (Cap Kaki Tiga)", Jurnal Privat Law, Vol. 2, Issue 5, 2016.

Rakhmita Desmayanti, "Tinjauan Umum Perlindungan Merek Terkenal Sebagai Daya Pembeda Menurut Perspektif Hukum Di Indonesia", Jurnal Cahaya Keadilan, Vol. 6, Issue 1, 2018.

Yayan Hanapi, "Pelaksanaan Perlindungan Hukum Merek Untuk Pengusaha Kerajinan Sulaman Karawo di Gorontalo", Gorontalo Law Review, Vol. 1, Issue $2,2018$.

\section{Legal Documents}

Undang-Undang Nomor 20 Tahun 2016 tentang Merek dan Indikasi Geografis [Law Number 20 of 2016 on Trademarks and Geographical Indications]

Undang-Undang Nomor 5 Tahun 1999 tentang Larangan Praktek Monopoli Persaingan Usaha Tidak Sehat [Law Number 5 of 1999 on the Prohibition of Monopolistic Practices for Unfair Business Competition] 